\title{
CLIMATE IN THE GREAT LAKES REGION BETWEEN 14,000 AND 4000 YEARS AGO FROM ISOTOPIC COMPOSITION OF CONIFER WOOD
}

\author{
Steven W Leavitt ${ }^{1,2} \bullet$ Irina P Panyushkina $^{1} \bullet$ Todd Lange $^{3} \bullet$ Alex Wiedenhoeft $^{4} \bullet$ Li Cheng $^{1} \bullet$ \\ R Douglas Hunter ${ }^{5}$ John Hughes ${ }^{6} \cdot$ Frank Pranschke $^{7} \bullet$ Allan F Schneider $^{8} \bullet$ Joseph Moran $^{9} \bullet$ \\ Ron Stieglitz ${ }^{9}$
}

\begin{abstract}
The isotopic composition of ancient wood has the potential to provide information about past environments. We analyzed the $\delta^{13} \mathrm{C}, \delta^{18} \mathrm{O}$, and $\delta^{2} \mathrm{H}$ of cellulose of conifer trees from several cross-sections at each of 9 sites around the Great Lakes region ranging from $\sim 4000$ to 14,000 cal BP. Isotopic values of Picea, Pinus, and Thuja species seem interchangeable for $\delta^{18} \mathrm{O}$ and $\delta^{2} \mathrm{H}$ comparisons, but Thuja appears distinctly different from the other 2 in its $\delta^{13} \mathrm{C}$ composition. Isotopic results suggest that the 2 sites of near-Younger Dryas age experienced the coldest conditions, although the Gribben Basin site near the Laurentide ice sheet was relatively dry, whereas the Liverpool site $500 \mathrm{~km}$ south was moister. The spatial isotopic variability of 3 of the 4 sites of Two Creeks age shows evidence of an elevation effect, perhaps related to sites farther inland from the Lake Michigan shoreline experiencing warmer daytime growing season temperatures. Thus, despite floristic similarity across sites (wood samples at 7 of the sites being Picea), the isotopes appear to reflect environmental differences that might not be readily evident from a purely floristic interpretation of macrofossil or pollen identification.
\end{abstract}

\section{INTRODUCTION}

The late Pleistocene and early Holocene environments of the Great Lakes area have fortuitously promoted preservation of wood as a result of various glacial, alluvial, aeolian, bog, and lacustrine processes. Wood is a particularly promising resource for annual- to sub-annual-resolution environmental reconstructions through tree rings, which may be analyzed by a wide range of proxy measurements, such as total ring width, latewood and earlywood width, wood density, cell diameter, cell-wall thickness, stable-isotope composition, and elemental analysis. The quality of preservation limits which of these proxy measurements may be reliably applied, but continued interest in the Pleistocene-Holocene transition and climate variability within the Holocene motivates exploitation of this wood resource.

Stable-isotope analysis of wood, on which this study focuses, has now been applied in a variety of modern studies. Although the models of stable-isotope fractionation in plants (trees) tend to be fairly complex, with numerous potential effects on isotope composition (Farquhar et al. 1982; Roden et al. 1999), there is surprisingly abundant empirical evidence for strong and direct relationships between stable-isotope composition and select climate parameters. For example, stable-carbon isotopes $\left(\delta^{13} \mathrm{C}\right)$ have been found to be commonly related to environmental moisture conditions such as drought (Leavitt and Long 1989), precipitation (Hemming et al. 1998), and relative humidity (Saurer and Siegenthaler 1989). Stable-oxygen $\left(\delta^{18} \mathrm{O}\right)$ and stable-hydrogen $\left(\delta^{2} \mathrm{H}\right)$ isotopic composition have been found to be related to temperature (associated with source meteoric water) and humidity (e.g. Yapp and Epstein 1982; Gray and Thompson 1976; Edwards and Fritz 1986; Roden et al.

\footnotetext{
${ }^{1}$ Laboratory of Tree-Ring Research, University of Arizona, Tucson, Arizona 85721, USA.

${ }^{2}$ Corresponding author. Email: sleavitt@u.arizona.edu.

${ }^{3}$ Department of Physics, University of Arizona, Tucson, Arizona 85721, USA.

${ }^{4}$ Center for Wood Anatomy Research, USDA Forest Products Laboratory, One Gifford Pinchot Drive, Madison, Wisconsin 53726-2398, USA.

${ }^{5}$ Biological Sciences, Oakland University, Rochester, Michigan 48309-4476, USA.

${ }^{6}$ Retired. Department of Geography, Earth Science, Conservation, and Planning, Northern Michigan University, Marquette, Michigan 49855, USA.

${ }^{7}$ Retired. Department of Geology, Northeastern Illinois University, Chicago, Illinois 60625-4699, USA.

${ }^{8}$ Retired. Department of Geology, University of Wisconsin-Parkside, Kenosha, Wisconsin 53141-2000, USA.

${ }^{9}$ Retired. Department of Geology, University of Wisconsin-Green Bay, Green Bay, Wisconsin 54311-7001, USA.
} 
1999). Typical ranges of isotopic variability among trees of the same species at a site have been reported on the order of 2-3\% for $\delta^{13} \mathrm{C}$ (Leavitt and Long 1984), 10-20\%o for $\delta^{2} \mathrm{H}$ (Ramesh et al. 1985), and $1-2 \%$ o for $\delta^{18} \mathrm{O}$ (Saurer et al. 1997), but there may also be differences among species (e.g. Stuiver and Braziunas 1987).

The isotopic composition of European Pleistocene-Holocene wood has been examined in several studies. Becker et al. (1991) analyzed $\delta^{13} \mathrm{C}$ and $\delta^{2} \mathrm{H}$ in European pine tree rings dating back to the end of the Younger Dryas cold event $\left(\sim 10,000{ }^{14} \mathrm{C} \mathrm{BP}\right)$ and discovered a shift suggesting warmer temperatures and possibly lower humidity in the Preboreal period that immediately followed. Friedrich et al. (1999) filled in and extended this record with new samples and found that an isotope lag in climate response at the beginning of the warmer Preboreal period might be explained by the influence of increased meltwater on the floodplain on which the trees grew as alpine glaciers melted after the Younger Dryas. Mayr et al. (2003) analyzed $\delta^{13} \mathrm{C}$ and $\delta^{2} \mathrm{H}$ in European oak tree rings and found evidence of climate variability over the past $8500 \mathrm{yr}$. For example, a marked negative shift of both isotopes around $6200 \mathrm{BC}$ is coincident with a climate event associated with large meltwater discharge from the collapsing Laurentide ice sheet. In North America, Edwards and Fritz (1986) analyzed $\delta^{18} \mathrm{O}$ and $\delta^{2} \mathrm{H}$ in a sequence of wood fragments at a site in Ontario, Canada, near the Great Lakes, to infer changes in temperature and humidity over most of the Holocene.

We have been systematically locating sites and samples of wood from throughout the Great Lakes area dating to between about 14,000 and $4000 \mathrm{yr}$ ago, and this study is our first effort to discern stable-isotope changes over this period. This investigation concentrates on conifer species in order to eliminate effects of isotopic differences common between angiosperm and gymnosperm taxa (e.g. Stuiver and Braziunas 1987; Leavitt and Newberry 1992). Although a single species would be ideal, as climate changed over this period the dominant species changed, and therefore Picea dominates the older portion of our record and Thuja and Pinus comprise the mid-Holocene collection. This study employs whole-stem (rather than individual tree-ring) analysis to look at long-term changes over time and even at spatial variability where there are multiple sites of the same age. Such bulk wood isotopic analysis can be productive even if individual tree rings cannot be readily analyzed as a result of unclear ring boundaries and poor preservation, because isotopic alteration of wood cellulose seems to be negligible during decomposition, at least in the case of carbon and hydrogen isotopes (Yapp and Epstein 1977).

\section{METHODS}

Wood from 9 sites for the period from 14,000 to $4000 \mathrm{cal} \mathrm{BP,} \mathrm{which} \mathrm{encompasses} \mathrm{major} \mathrm{deglaciation}$ and Holocene events, was obtained from previous collections or new field campaigns (Figure 1, Table 1). The radiocarbon ages from the Liverpool site suggest it is late Younger Dryas age, whereas the Gribben Basin site appears to occur just after the Younger Dryas event. Although the reported ${ }^{14} \mathrm{C}$ ages of the 4 oldest sites (Two Creeks, Green Bay GB, Green Bay AH, and New Denmark) are slightly different, they are likely associated with the Two Creeks interval when an extensive spruce forest became established in front of the retreating Laurentide ice sheet, only to be subjected to deteriorating climate conditions as the ice sheet readvanced and then to eventual overriding by the ice sheet. Based on tree-ring study of wood from the Two Creeks type locality (Kaiser 1994), at least $252 \mathrm{yr}$ are represented in this time interval. Despite the discrepancies in ${ }^{14} \mathrm{C}$ ages, the similarity in geologic deposits in which the wood is entombed and the relatively long age of the Two Creeks period suggest that in reality the trees represented in the wood from the 4 sites may have existed contemporaneously. 


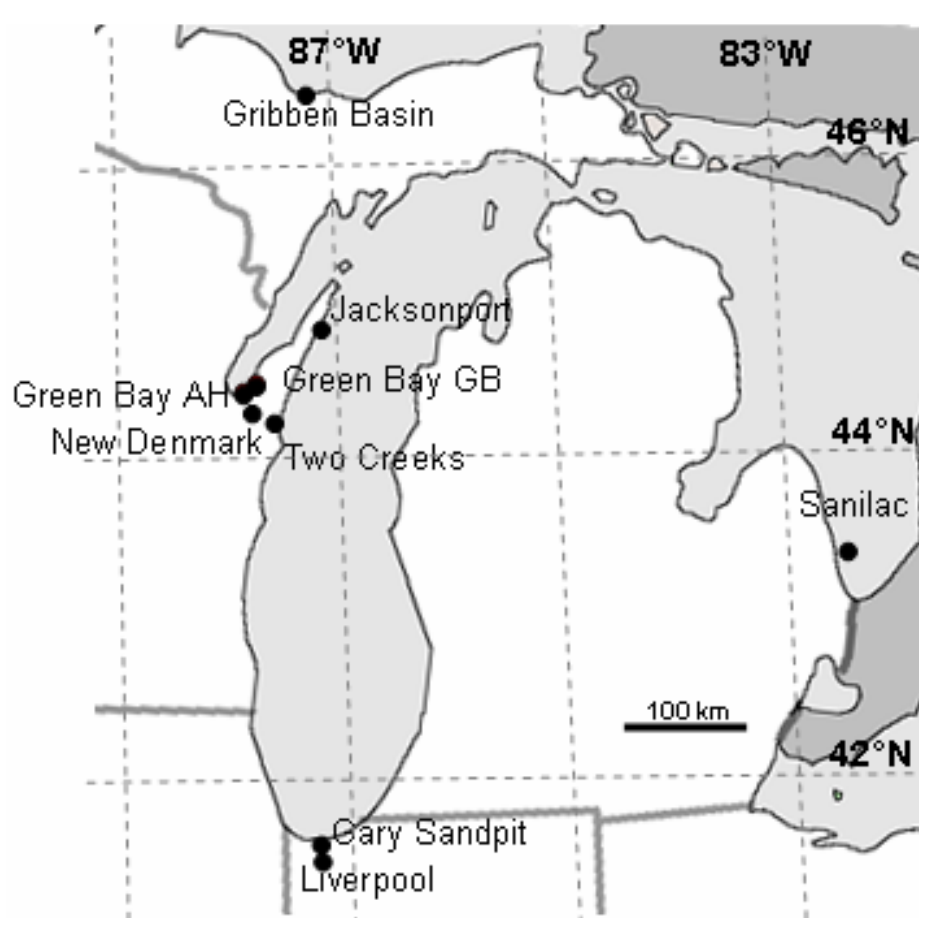

Figure 1 Location of conifer sites from which wood was analyzed in this study

Wood at some sites came from in situ stumps, whereas at other sites wood came from logs or a mix of logs and stumps. At most sites, wood was preserved in sandy sediments, but at 2 of the sites, Jacksonport and Sanilac, wood was submerged in Lake Michigan and Lake Huron, respectively. Wood older than 11,000 cal BP was all spruce, and probably mostly white spruce (Picea abies), except at the Liverpool site where the wood was probably black spruce (Picea mariana). Multiple samples (usually $3-5$ ) were analyzed to better quantify the mean site isotopic composition and express isotopic variability. Only 2 samples were analyzed from the Gary Sandpit site, which were the only 2 substantial wood pieces collected. For most sites, previous ${ }^{14} \mathrm{C}$ dates existed on wood other than samples that we had, but for others we obtained additional or the first exclusive AMS dates (cellulose was isolated, combusted to $\mathrm{CO}_{2}$, and converted to graphite for AMS targets). For example, in the case of the newly discovered Gary site, we obtained ${ }^{14} \mathrm{C}$ dates directly on the 2 wood pieces used in stable-isotope analysis. Also, we obtained dates on 2 of the 4 pieces of wood from the Green Bay $\mathrm{AH}$ site used for stable isotopes. The standard deviation error associated with most individual ages is $50-100 \mathrm{yr}$, but for most sites multiple dates provide a better average age.

Most wood was subsampled by drilling 2 radii of $\sim 3$-mm diameter from the outside to the inside of each cross-section and carefully collecting the fine wood fragments so produced (estimated to be finer than 20 mesh). In a few cases, only a single radius was drilled when the available piece of wood contained only a portion of the circumference of the original $\log$ (i.e. it was a pie-shaped piece). The 5 specimens from the Sanilac site were subsampled as thin, full cross-sections that were ground to 20 mesh. Mature trees from each site with similar ages were selected subject to the limitations of available samples. The approximate ages (number of rings) of the samples being analyzed at each of the sites are as follows: Gary Sandpit (90-129), Jacksonport (38-75), Sanilac (12-87), Gribben Basin (67-137), Liverpool (49-68), Two Creeks (141-178), New Denmark (53-156), Green Bay AH (120-273), and Green Bay GB (156-303). 
Table 1 Information on sites, species, wood source, number of samples analyzed, and age. ${ }^{14} \mathrm{C}$ ages are displayed without standard deviation, but in all but one case standard deviations of 40 to $390{ }^{14} \mathrm{C}$ $\mathrm{yr}$ are reported in the original sources. The calibrated age is the midpoint of the 2- $\sigma$ range of ages derived from the ${ }^{14} \mathrm{C}$ dates and their error according to the CALIB 5 program (Stuiver and Reimer 1993; Reimer et al. 2004).

\begin{tabular}{|c|c|c|c|c|c|c|}
\hline Site & $\begin{array}{l}\mathrm{Nr} \text { of } \\
\text { samples }\end{array}$ & Species & Wood form & $\begin{array}{l}\text { Age }^{\mathrm{a}} \\
\left({ }^{14} \mathrm{C} \mathrm{BP}\right)\end{array}$ & $\operatorname{Ref}^{b}$ & $\begin{array}{l}\text { Calibrated age, } \\
2-\sigma \text { range } \\
(\text { cal BP) }\end{array}$ \\
\hline Gary Sandpit & 2 & Pinus & $\log s$ & $3095 / 4040$ & 1 & $\begin{array}{l}3980 \\
3170-4790\end{array}$ \\
\hline Jacksonport & 4 & Thuja/Picea & stumps & 6500 & 2 & $\begin{array}{l}7450 \\
7280-7620\end{array}$ \\
\hline Sanilac & 5 & Thuja & stumps & 6420-7095 & 3 & $\begin{array}{l}7610 \\
7290-7930\end{array}$ \\
\hline Gribben Basin & 5 & Picea & stumps & $9660-10,290$ & 4,5 & $\begin{array}{l}11,440 \\
10,780-12,100\end{array}$ \\
\hline Liverpool & 4 & Picea & stumps & 9920-10,420 & 6 & $\begin{array}{l}11,740 \\
10,740-12,730\end{array}$ \\
\hline Two Creeks & 4 & Picea & $\begin{array}{l}\text { stumps/ } \\
\operatorname{logs}\end{array}$ & $11,560-12,035$ & 7,8 & $\begin{array}{l}13,660 \\
13,280-14,030\end{array}$ \\
\hline New Denmark & 4 & Picea & $\begin{array}{l}\text { stumps/ } \\
\operatorname{logs}\end{array}$ & 11,630 & 9 & $\begin{array}{l}13,490 \\
13,300-13,680\end{array}$ \\
\hline Green Bay AH & 4 & Picea & $\log s$ & $11,140 / 11,345$ & 10 & $\begin{array}{l}13,130 \\
12,920-13,340\end{array}$ \\
\hline Green Bay GB & 3 & Picea & $\log s$ & 11,940 & 11 & $\begin{array}{l}14,060 \\
13,100-15,010\end{array}$ \\
\hline
\end{tabular}

an most cases, age refers to "site" age determined by dating other pieces of wood in the original studies. However, the age ranges for the Gary Sandpit and Sanilac sites are based on dates of the sample suite analyzed in this study, and the age range for the Green Bay AH site is based on dates of 2 of the 4 samples analyzed in this study.

b References: 1 - Discovered in this study: AA56633 $=4040 \pm 40$, AA56634 $=3095 \pm 44$ BP; 2 - Dates of C Larson (personal communication, 2005): W-6466 $=6500 \pm 100$, W-6467 $=6480 \pm 90$, W-6468 $=6540 \pm 100 \mathrm{BP}$, with mean age reported in Pranschke and Shabica (1993); 3 - Hunter et al. (2006); 4 - Lowell et al. (1999); 5 - Pregitzer et al. (2000); 6 - "Liverpool East" site of Schneider and Hansel (1990); 7 - Leavitt and Kalin (1992); 8 - Kaiser (1994); 9 - Moran et al. (1988), ISGS$660=11,630 \pm 80 \mathrm{BP} ; 10$ - Discovered in this study: AA62029 = 11,140 \pm 65 , AA62036 = 11,345 \pm 70 BP; 11 - unpublished report by Thwaites (1958).

All fine wood samples were initially converted to holocellulose by the Jayme-Wise method through a procedure slightly modified from Leavitt and Danzer (1993) using commercial digestion pouches (ANKOM Technology, Boston, MA) instead of glass fiber filter paper to contain the individual samples during batch processing. Samples were first extracted with toluene/ethanol and then with ethanol organic solvents in a soxhlet extraction apparatus, followed by boiling in deionized water. Samples were delignified in an acetic acid-acidified, sodium chlorite aqueous solution at $70^{\circ} \mathrm{C}$, and then thoroughly rinsed in deionized water. All holocellulose samples were converted to $\alpha$-cellulose by treatment in a $17 \% \mathrm{NaOH}$ solution according to the methods described in Sternberg (1989). Because a residual brownish-red color remaining in some of the samples was thought to represent iron oxides that could bias $\mathrm{O}$-isotope and maybe $\mathrm{H}$-isotope analysis, $\sim 0.2-0.5 \mathrm{~g}$ of $\alpha$-cellulose from all samples was further treated with $10 \%(\mathrm{w} / \mathrm{v})$ oxalic acid solution for 2 days (oxalic solution replaced with a fresh batch the 2nd day) to dissolve the oxides, followed by 10 rinses with deionized water over a 3 rd day. This treatment successfully removed all residual color from the white $\alpha$-cellulose. A split 
of $\alpha$-cellulose was further nitrated with fuming nitric acid (Sternberg 1989) to remove exchangeable hydrogen atoms and produce nitrocellulose for $\mathrm{H}$-isotope analysis.

Samples were analyzed on a Finnigan Delta-Plus mass spectrometer in flow-through mode. Working standards of known isotopic composition were run every 3 to 6 samples to monitor mass spectrometer reproducibility (analytical precision) and to adjust sample results for any offset in absolute value of the standard. For $\delta^{13} \mathrm{C}, \alpha$-cellulose samples were combusted to $\mathrm{CO}_{2}$ in an elemental analyzer with combustion products carried by a helium carrier gas and separated in a gas chromatograph before the gas stream was introduced into the mass spectrometer. Separate $\alpha$-cellulose subsamples were weighed out for $\delta^{18} \mathrm{O}$ and nitrocellulose samples for $\delta^{2} \mathrm{H}$, pyrolized/combusted to $\mathrm{CO}$ and $\mathrm{H}_{2}$, separated by gas chromatography, and admitted into the mass spectrometer. Isotopic results are reported with respect to the PDB standard for $\delta^{13} \mathrm{C}$ and the V-SMOW standard for $\delta^{18} \mathrm{O}$ and $\delta^{2} \mathrm{H}$. During the $\delta^{13} \mathrm{C}$ sample runs, the repeated analysis of the acetylnide working standard indicated a precision ( 1 standard deviation) of $0.04-0.08 \%$, whereas for the $\delta^{18} \mathrm{O}$ and $\delta^{2} \mathrm{H}$ sample runs, the benzoic acid working standard showed a precision of $0.1-0.6 \%$ and $2 \%$, respectively. Multiple analyses of select samples gave precision (1 standard deviation) of $0.01-0.04 \%$ o for $\delta^{13} \mathrm{C}, 0.1 \%$ o for $\delta^{18} \mathrm{O}$, and $0-6 \%$ for $\delta^{2} \mathrm{H}$, suggesting analytical performance for cellulose analysis of $\delta^{13} \mathrm{C}$ and $\delta^{18} \mathrm{O}$ was as good or better than the corresponding working standards, but $\delta^{2} \mathrm{H}$ analysis of $\alpha$-cellulose may not have been as stable as for the benzoic acid or some heterogeneity was introduced during the more elaborate nitrocellulose preparation.

${ }^{14} \mathrm{C}$ ages (BP) were converted to calibrated ages (cal BP relative to AD 1950) using the CALIB5 program (Stuiver and Reimer 1993; Stuiver et al. 1998; Reimer et al. 2004).

\section{RESULTS}

All 3 isotopes exhibit variability over the time period from 14,000 to 4000 cal BP (Figure 2). The patterns of isotope change are generally consistent and smooth, with the notable exception of the $\delta^{13} \mathrm{C}$ values of the Sanilac and Jacksonport sites at 7610 and 7450 cal BP, respectively, whose means differ by $\sim 1.5 \%$. This appears to be a species effect, as evidenced by 1 Thuja $\delta^{13} \mathrm{C}$ from the Jacksonport site having a value similar to the 5 Thuja values from the Sanilac site (all 6 are likely to be Thuja occidentalis), whereas the other 3 Picea values at Jacksonport are $\sim 2 \%$ o ${ }^{13} \mathrm{C}$-depleted (more isotopically negative). Could there be $\delta^{13} \mathrm{C}$ differences between Thuja and Picea or Pinus and Picea species? If the wood from the 1991 ring of 2 Pinus resinosa and 4 Picea glauca trees from near Madison, Wisconsin, is any indication (Leavitt 2002), the Pinus and Picea are not significantly different and can be used interchangeably in this study. Likewise, the mean $\delta^{13} \mathrm{C}$ values of the 1988 and 1989 rings from a site near Marquette, Michigan, differed by only $0.3-0.4 \%$ o for co-occurring Picea glauca (pooled from 4 trees), Pinus resinosa (pooled from 2 trees), and Pinus glauca (pooled from 4 trees) (Leavitt, forthcoming). No similar comparative $\delta^{13} \mathrm{C}$ data exist for Thuja with Picea and Pinus, but the results here from the 2 sites at $\sim 7500$ cal BP suggest the Picea $\delta^{13} \mathrm{C}$ may be more directly comparable to trees of other periods than are the Thuja values. Hence, the long-term trend line in the $\delta^{13} \mathrm{C}$ data would best be guided by the Jacksonport Picea rather than the Sanilac Thuja.

Within sites, the $\delta^{13} \mathrm{C}$ isotopic variability ( \pm 2 standard errors) is $1-2 \%$, with the Green Bay AH site showing the lowest variation and Jacksonport the highest. The Jacksonport variability is misleading because the error of $\sim 2 \%$ includes the 1 Thuja value, but would be closer to $1 \%$ if only the 3 Picea values are considered. The $1-2 \%$ variability is similar to that observed among conifer trees at modern sites (Leavitt and Long 1986, 1988; Leavitt et al. 2002). 

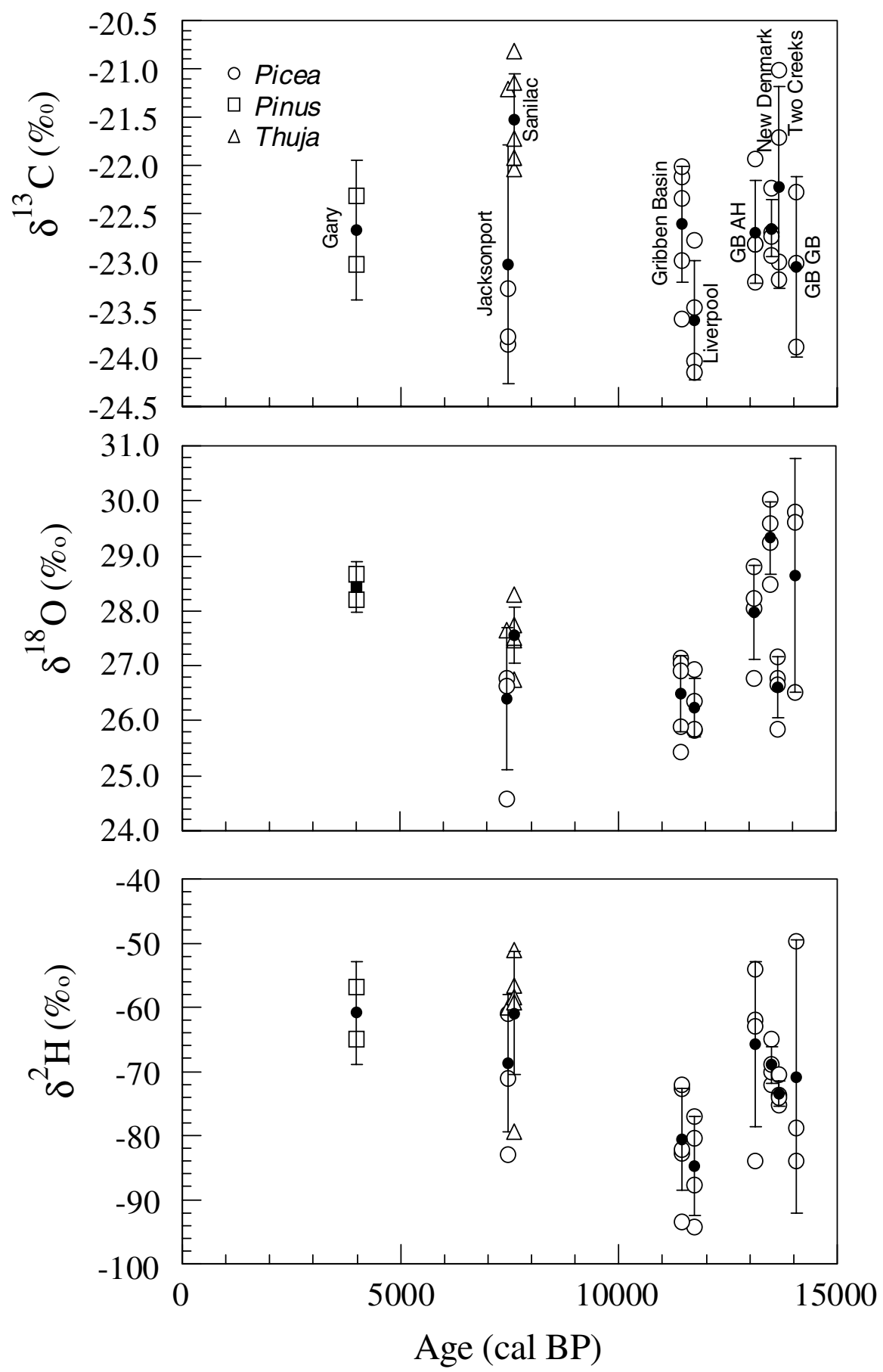

Figure $2 \delta^{13} \mathrm{C}$ (top), $\delta^{18} \mathrm{O}$ (middle), and $\delta^{2} \mathrm{H}$ (bottom) chronologies from wood analyzed in this study plotted against cal BP (corresponding ages in ${ }^{14} \mathrm{C} \mathrm{BP}$; the errors associated with the calibrated ages are given in Table 1). The isotopic compositions of individual wood samples are open circles, and the means are the solid circles with vertical error bars representing 2 standard errors about the mean. 
Unfortunately, no similar comparative isotopic $\delta^{18} \mathrm{O}$ and $\delta^{2} \mathrm{H}$ data exist for Thuja, Picea, and Pinus species at the same site. Unlike $\delta^{13} \mathrm{C}$, the $\delta^{18} \mathrm{O}$ and $\delta^{2} \mathrm{H}$ results (Figure 2) are consistent across species and sites, allowing direct comparisons independent of the taxonomy of the material. In the $\delta^{18} \mathrm{O}$ plot, the 2 sites at $\sim 11,600 \mathrm{cal}$ BP consistently had the lowest values. Liverpool $\delta^{18} \mathrm{O}$ values were significantly lower $(t$ test) than Green Bay GB $(p=0.051)$, New Denmark $(p<0.0005)$, Green Bay AH $(p<0.05)$, Sanilac $(p<0.01)$, and Gary $(p<0.01)$, while Gribben Basin $\delta^{18} \mathrm{O}$ values were significantly lower than Green Bay GB $(p=0.053)$, New Denmark $(p<0.001)$, Green Bay AH $(p<0.05)$, Sanilac $(p<0.05)$, and Gary $(p<0.05)$. The $\delta^{2} \mathrm{H}$ of 2 sites at 11,600 cal BP likewise tended to be the lowest. Liverpool $\delta^{2} \mathrm{H}$ values were significantly lower than Two Creeks $(p<0.05)$, New Denmark $(p<0.01)$, Green Bay AH $(p<0.05)$, Sanilac $(p<0.01)$, Jacksonport $(p=0.051)$, and Gary $(p<0.05)$, while Gribben Basin values were significantly lower than New Denmark $(p<0.05)$, Green Bay AH $(p=0.077)$, Sanilac $(p<0.05)$, and Gary $(p<0.05)$. In addition to having isotopically greater $\left({ }^{18} \mathrm{O}-\right.$ and ${ }^{2} \mathrm{H}$-enriched) values than Gribben Basin and Liverpool, the Gary site at $4000 \mathrm{cal}$ BP was enriched relative to Two Creeks for $\delta^{18} \mathrm{O}(p<0.05)$ and $\delta^{2} \mathrm{H}(p<0.05)$. For the cluster of 4 Two Creeks-age sites, the Green Bay AH and Green Bay GB sites were not distinguishable for any isotopes, and only Green Bay AH was isotopically heavier than Two Creeks $(p<0.05)$. However, the New Denmark site was enriched relative to the Two Creeks site for both $\delta^{18} \mathrm{O}(p<0.001)$ and for $\delta^{2} \mathrm{H}$ $(p<0.05)$. The Sanilac site $\delta^{18} \mathrm{O}$ and $\delta^{2} \mathrm{H}$ values were enriched relative to both Gribben Basin $(p<0.05)$ and Liverpool $(p<0.01)$ but not different from Gary and nor was Jacksonport.

\section{DISCUSSION}

\section{Isotopic Patterns through Time}

The broad trend of $\delta^{13} \mathrm{C}$ change is one of most ${ }^{13} \mathrm{C}$-depleted (most negative) values for the Younger Dryas (Liverpool site) at 11,700 cal BP (and for the Jacksonport site if only the 3 Picea trees are considered) and less depleted values both in older and younger sites. Just a few hundred years after the Liverpool site, the Gribben Basin trees are less ${ }^{13} \mathrm{C}$-depleted than Liverpool $(t$ test significance, $p<0.056$ ) but statistically indistinguishable from the 4 Two Creeks-age sites. Trees at 5 of the 6 oldest sites were growing in the vicinity of an advancing Laurentide ice sheet, i.e. within tens of kilometers. The Liverpool site, however, was located $400-500 \mathrm{~km}$ south of the ice sheet. Although the factors influencing $\delta^{13} \mathrm{C}$ are complex, according to analysis of air trapped in the Taylor Dome ice core (Smith et al. 1999), between 14,000 and 11,400 cal BP atmospheric $\mathrm{CO}_{2}$ concentration rose from 237 to $264 \mathrm{ppm}$, and $\delta^{13} \mathrm{C}$ of air $\mathrm{CO}_{2}$ varied between -6.9 and $-6.7 \%$. Thus, changes in $\delta^{13} \mathrm{C}$ of air would not contribute to the $\delta^{13} \mathrm{C}$ differences we see among the 6 sites, but lower $\mathrm{CO}_{2}$ concentrations could be consistent with higher tree $\delta^{13} \mathrm{C}$ values for the 4 sites at Two Creeks time. However, the Gribben Basin site does not show a decline in $\delta^{13} \mathrm{C}$ that might be linked to the $\mathrm{CO}_{2}$ rise, so another factor may be dominating the pattern, namely moisture. The summer (growing season) position of the Arctic Frontal Zone (Bryson et al. 1970) is hypothesized to be close to the continental glacier front. This would contribute dry air in the growing season, as would katabatic winds flowing southward off the ice sheet front. Such dry conditions would promote elevated plant $\delta^{13} \mathrm{C}$ at the Two Creeks-age and Gribben Basin sites, whereas the isotopic values of the wood at the Liverpool site much farther from the ice front suggest moister conditions. It is worth noting that we do not have comparative isotopic information on black spruce (Picea mariana) and white spruce (Picea glauca) at the same site. We observed possible black spruce cones at the Liverpool site, whereas dominant spruce species reported from the Gribben Basin site are not distinguished (Lowell et al. 1999), so we do not know if there is a species effect on isotope differences here. 
The models describing $\delta^{18} \mathrm{O}$ and $\delta^{2} \mathrm{H}$ fractionation in plants are complex but are in line with empirical relationships showing a strong relationship between these isotopes and temperature. Our results suggest the coldest temperatures occurred around the Younger Dryas event 11,600 cal BP, becoming warmer during the Holocene ("mid-Holocene warm period" at 5000-7000 cal BP [Winkler et al. 1986; Kerwin et al. 1999]). The Two Creeks-age sites could be characterized as cool, but not as cool as the 2 sites at or near the end of the Younger Dryas event. Furthermore, the coolness of the near-Younger Dryas sites cannot be simply a function of proximity to the Laurentide ice sheet, because although the Gribben Basin site was in relatively close proximity, the Liverpool site was probably positioned over $500 \mathrm{~km}$ south of the ice sheet, thereby providing independent evidence for a cool North American Younger Dryas period (Shane and Anderson 1993). Additionally, the Two Creeks site was probably influenced to some degree by rising proglacial lake levels, at least late in its lifespan (Kaiser 1994), after which it was overridden by the ice sheet. Likewise, although not overridden, the Gribben Basin site was influenced by outwash emerging from the approaching ice front (Lowell et al. 1999). Because the proglacial lake and outwash water would probably have isotopically light $\delta^{18} \mathrm{O}$ and $\delta^{2} \mathrm{H}$ values, the difference between Gribben Basin and Two Creeks lends more credence to a possible environmental temperature difference between Two Creeks age and Younger Dryas age.

The qualitative patterns of moisture and temperature inferred from $\delta^{13} \mathrm{C}, \delta^{18} \mathrm{O}$, and $\delta^{2} \mathrm{H}$ among these sites might be generalized as follows:

\begin{tabular}{lll}
\hline & Temperature & Moisture \\
\hline Two Creeks-age & cool & dry \\
Younger Dryas & & \\
South & cold & wet \\
North & cold & dry \\
& & \\
Mid-Holocene & & \\
7500 cal BP & warming & wet \\
4000 cal BP & warm & dry \\
\hline
\end{tabular}

Edwards and Fritz (1986) did a more quantitative reconstruction of temperature and moisture (humidity) with mechanistic modeling of isotopes in wood, which showed progressive warming from the coldest and driest environment at $\sim 12,000 \mathrm{BP}$ to the warmest and moistest at $4000 \mathrm{BP}$, the time span of our results. Their reconstruction is therefore similar to ours for temperature, but our reconstruction suggests dryness at $4000 \mathrm{BP}$ rather than wetness based on $\delta^{13} \mathrm{C}$ of the Gary Pinus, which tends to be greater than the Jacksonport Picea $(p=0.072)$. Their study analyzed 11 pieces of ${ }^{14} \mathrm{C}$-dated wood from a "kettle-fill" sedimentation sequence near Toronto, Ontario, several hundred $\mathrm{km}$ east of our region. There was only 1 sample for each age in their chronology, and interestingly, the $\delta^{18} \mathrm{O}$ was not particularly strongly correlated with $\delta^{2} \mathrm{H}$ in the period prior to $8700 \mathrm{BP}$.

There are some other proxy indicators that are consistent with our results. For example, Booth et al. (2002), using pollen and other proxy indicators in the Michigan Upper Peninsula, suggest dry conditions from 8600 to $6600 \mathrm{cal} \mathrm{BP}$ followed by an increase in moisture in the northern part of the Great Lakes region, in contrast to a reported drying in the southern part of the region beginning about 6500 cal BP. Our post- 8000 cal BP results are from sites in the southern region and are con- 
sistent with southern region moisture followed by drying. Furthermore, the coldest conditions in our record at Younger Dryas time are also seen in the pollen and macrofossil record developed by $\mathrm{Hu}$ (2000) just east of Lake Huron.

\section{Isotopic Patterns at the Two Creeks-Age Sites}

The 4 Two Creeks-age sites present an interesting opportunity to consider spatial isotopic differences. The Two Creeks site is about $55 \mathrm{~km}$ from the 2 Green Bay sites (Green Bay AH being $\sim 5 \mathrm{~km}$ $\mathrm{S}$ of Green Bay GB), whereas the New Denmark site is in an intermediate position ( $\sim 25 \mathrm{~km} \mathrm{WNW}$ of Two Creeks and $14 \mathrm{~km} \mathrm{SE}$ of Green Bay AH). The isotopic composition of these 4 sites is distinguished most clearly when their $\delta^{13} \mathrm{C}$ and $\delta^{18} \mathrm{O}$ values are plotted (Figure 3). Although their $\delta^{13} \mathrm{C}$ values alone overlap in large part, when $\delta^{18} \mathrm{O}$ is considered they seem to separate out by elevation, with the $\delta^{18} \mathrm{O}$ field increasing from Two Creeks (180 m asl) to Green Bay AH (224 m) to New Denmark $(268 \mathrm{~m})$. Although orographic effects would be expected to produce lower $\delta^{18} \mathrm{O}$ at higher elevations as rainout preferentially removes the heavy isotopes (a $40 \%$ o decline in $\delta^{2} \mathrm{H}$ per km rise found by Friedman and Smith [1970] in the Sierra Nevada would be $\sim 5 \%$ o decrease in $\delta^{18} \mathrm{O}$ per km), the observed pattern is the reverse. Such a shift would be consistent with more "continental" temperatures, i.e. warmer growing season days at the sites progressively farther inland, which are farther from moderating effects of the glacial Lake Michigan at that time. Indeed, the New Denmark site is the farthest away from the lake, and Green Bay AH is the next farthest, whereas Two Creeks and Green Bay GB are along the present shoreline. The Green Bay GB site is somewhat anomalous in that the wood was collected from a large wedge of peat and logs showing evidence of deformation, surrounded by a mixture of likely lacustrine deposits and overlain by glacial till. The mixing of sediment types, deformation, and lack of any trees/logs in growth position was interpreted by $\mathrm{F} T$ Thwaites (1958, unpublished report) as representing transport from elsewhere. However, Kendall and Coplen (2001) report a temperature gradient of about $+0.5 \% \circ \delta^{18} \mathrm{O}$ of precipitation per $1{ }^{\circ} \mathrm{C}$ in the eastern US, which would require a $6{ }^{\circ} \mathrm{C}$ difference between the shoreline and inland sites. Modern climate data from Two Rivers (near Two Creeks along the Lake Michigan shoreline) and Chilton (positioned inland 30-40 km SW of New Denmark) shows daytime high temperatures greater at Chilton by $3-5{ }^{\circ} \mathrm{C}$ in June-July-August than at Two Rivers (National Climate Data Center, U.S. climate normals, http://lwf.ncdc.noaa.gov/oa/ncdc.html). Temperature may thus play some role, but it probably cannot solely account for the observed pattern.

\section{$\delta^{18} \mathrm{O}$ and $\delta^{2} \mathrm{H}$ and Source Water}

The source of water contributing to photosynthesis derives from precipitation, but the final isotopic composition of photosynthates and tree-ring cellulose will depend on isotope fractionation effects during evaporation processes in the leaf and partial re-equilibration with stem water in the trunk at the site of cellulose formation (Roden et al. 1999). The relationship of $\delta^{18} \mathrm{O}$ and $\delta^{2} \mathrm{H}$ in precipitation is described by the "meteoric water line," for which there is a global regression line and local regressions such as for the Great Lakes area (Figure 4). For tree rings, the $27 \%$ o biochemical fractionation during photosynthesis (Yakir and DeNiro 1990) can be subtracted from the cellulose $\delta^{18} \mathrm{O}$ composition to more closely approximate the original water isotopic composition, whereas there is no major net biochemical fractionation for $\delta^{2} \mathrm{H}$ (Yakir and DeNiro 1990).

The $\delta^{18} \mathrm{O}$ and $\delta^{2} \mathrm{H}$ values of all samples in this study plot within a fairly restricted area in $\delta^{18} \mathrm{O}-\delta^{2} \mathrm{H}$ space (Figure 4) despite the range of locations, ages, and species. This cluster does not represent the isotopic composition of the original meteoric water because evaporation effects have not been accounted for. Furthermore, the $\delta^{18} \mathrm{O}$ and $\delta^{2} \mathrm{H}$ of the original meteoric water cannot be calculated 


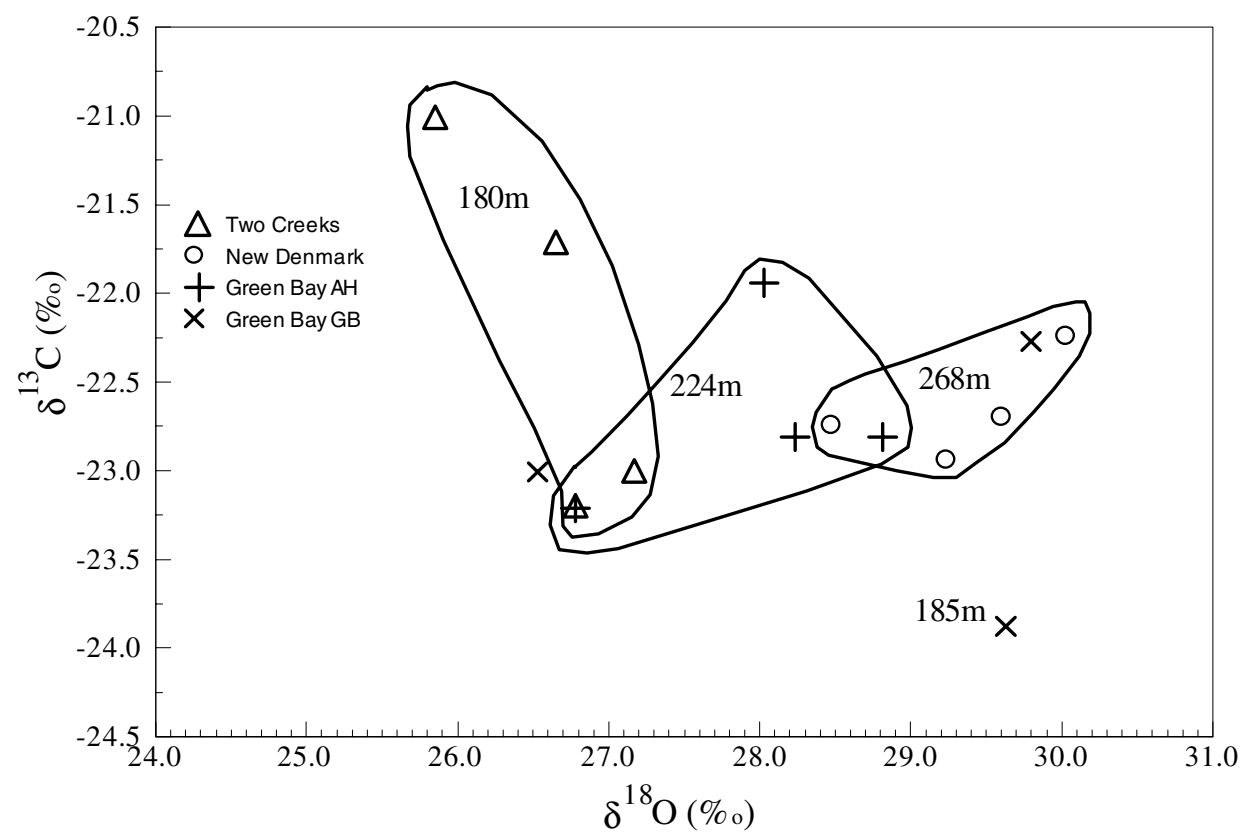

Figure 3 Plot of $\delta^{13} \mathrm{C}$ vs. $\delta^{18} \mathrm{O}$ for the 4 Two Creeks-age sites. Points from the Two Creeks, Green Bay AH, and New Denmark sites are outlined in their respective clusters, which show a pattern apparently related to their indicated elevation. Points from the Green Bay GB seem to spread across all other site values.

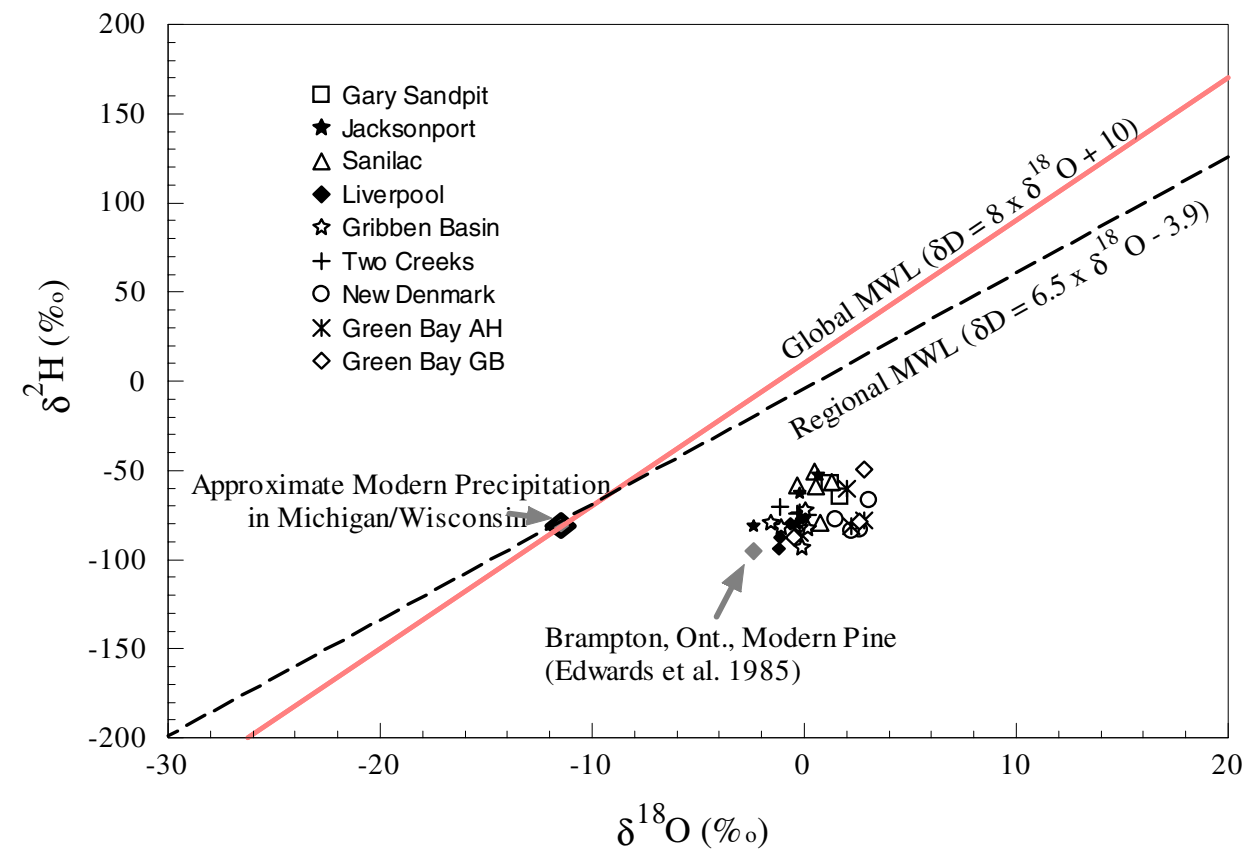

Figure 4 Plot of $\delta^{18} \mathrm{O}$ vs. $\delta^{2} \mathrm{H}$ for all of the wood samples analyzed in this study. The biochemical fractionation of $27 \%$ o was subtracted from the original wood $\delta^{18} \mathrm{O}$ values to estimate $\delta^{18} \mathrm{O}$ of the water used in photosynthesis, whereas the original $\delta^{2} \mathrm{H}$ values are used. The only available isotopic composition from a modern tree in the vicinity was reported by Edwards and Fritz (1986) from Brampton, Ontario. $\delta^{18} \mathrm{O}-\delta^{2} \mathrm{H}$ relationships for modern precipitation are illustrated with the global meteoric water line and a local meteoric line for the region encompassing the sites in this study, and a point along the meteoric water line approximates mean isotopic composition of precipitation (represented in stream water analysis) in Michigan and Wisconsin (Kendall and Coplen 2001). 
without some assumptions about relative humidity and isotopic composition of relative humidity (Roden et al. 1999). However, the isotopic composition of modern pine wood from Brampton, Ontario, a few hundred $\mathrm{km}$ east of the study region with an average growing-season relative humidity of $\sim 64 \%$ (Edwards and Fritz 1986), plots in the vicinity of the subfossil wood. Estimated mean isotopic composition of regional modern precipitation (Kendall and Coplen 2001) is also plotted for comparison. The displacement of the subfossil wood composition would be consistent with either greater evaporation effects (lower humidity) or meteoric water less depleted in ${ }^{2} \mathrm{H}$ and ${ }^{18} \mathrm{O}$ compared to the modern conditions.

\section{CONCLUSIONS}

The typical variability of $\delta^{13} \mathrm{C}, \delta^{18} \mathrm{O}$, and $\delta^{2} \mathrm{H}$ among trees within sites was about $1-2 \%$, $1-4 \%$, and $10-40 \%$, respectively. This indicates that sampling only a single piece of wood from a site to characterize the site's isotopic composition could produce values notably different from the site mean, which could therefore contribute to different trends than those observed here with multiple samples at each site.

It is likely that the $\delta^{13} \mathrm{C}$ differences of the similarly-aged Sanilac and Jacksonport sites are related to different genera, with Thuja being isotopically heavier; thus, interpretations of climate changes are better guided by spruce and pine isotopic composition, the similarities of which may be related to either ecological similarities, taxonomic affinity, or both. For $\delta^{18} \mathrm{O}$ and $\delta^{2} \mathrm{H}$, Thuja does not show anomalous values relative to spruce, and it therefore fits climate interpretations based on the other species. If cellulose $\delta^{13} \mathrm{C}$ contains a moisture signal and $\delta^{18} \mathrm{O}$ and $\delta^{2} \mathrm{H}$ contain a temperature signal as predicted by the models, the Younger Dryas event in this region was cold and dry near the Laurentide ice front and cold and moist $500 \mathrm{~km}$ south, even colder than the forest stands of Two Creeks age about $1500 \mathrm{yr}$ older. Both warming and drying appear to have occurred during the $6000 \mathrm{yr}$ of the Holocene after the Younger Dryas, but with only 3 sites in that 6000 -yr period we are unable to chart those changes at higher resolution.

Subfossil wood discoveries are valuable paleoclimate resources that can be exploited with stableisotope analysis. Wood from a sequence of sites of different ages can help reconstruct temporal environmental changes, but wood of similar age from different locations makes the best contribution in this regard, when available. This allows exploration of spatial environmental variability, as the environmental signal in wood from a single site may not be representative of a region because of microclimatic conditions, biases caused by ecological preferences of the taxa studied, or combinations thereof.

\section{ACKNOWLEDGMENTS}

Wood was fortuitously collected and archived from the Green Bay GB site by Hugh Iltis of the University of Wisconsin about 5 decades ago and kindly provided to us by Klaus Westphal, Director Emeritus of the University of Wisconsin Geology Museum. Curt Larson generously provided us with his unpublished ${ }^{14} \mathrm{C}$ dates for the Jacksonport site. Jim Burns helped with sample preparation, and we thank the Laboratory of Isotope Geochemistry in the Department of Geosciences (Chris Eastoe and David Dettman), University of Arizona, for stable-isotope analysis, and the NSF-AMS Facility and the Conventional Radiocarbon Laboratory at the University of Arizona for dating of wood associated with the Gary Sandpit, Sanilac, and Green Bay AH sites. This study was supported by NSF Earth System History program under Grant \#ATM-0213696. 


\section{REFERENCES}

Becker B, Kromer B, Trimborn P. 1991. A stable-isotope tree-ring timescale of the late Glacial-Holocene boundary. Nature 353:647-9.

Booth RK, Jackson ST, Thompson TA. 2002. Paleoecology of a northern Michigan Lake and the relationship among climate, vegetation, and Great Lakes water levels. Quaternary Research 57:120-30.

Bryson RA, Baerreis DA, Wendland WM. 1970. The character of late-glacial and post-glacial climatic changes. In: Dort WJ, Jones JK, editors. Pleistocene and Recent Environments of the Central Great Plains. Lawrence: University of Kansas Press. p 53-74.

Edwards TWD, Fritz P. 1986. Assessing meteoric water composition and relative humidity from ${ }^{18} \mathrm{O}$ and ${ }^{2} \mathrm{H}$ in wood cellulose: paleoclimatic implications for southern Ontario, Canada. Applied Geochemistry 1:71523.

Farquhar GD, O'Leary MH, Baxter JA. 1982. On the relationship between carbon isotope discrimination and intercellular carbon dioxide concentration in leaves. Australian Journal of Plant Physiology 9:121-37.

Friedman I, Smith GI. 1970. Deuterium content of snow cores from Sierra Nevada area. Science 169:467-70.

Friedrich M, Kromer B, Spurk M, Hoffman J, Kauser KF. 1999. Paleo-environment and radiocarbon calibration as derived from Lateglacial/Early Holocene tree-ring chronologies. Quaternary International 61:27-39.

Gray J, Thompson P. 1976. Climatic information from ${ }^{18} \mathrm{O} /{ }^{16} \mathrm{O}$ ratios of cellulose in tree rings. Nature 262: 481-2.

Hemming DL, Switsur VR, Waterhouse JS, Heaton THE, Carter AHC. 1998. Climate variation and the stable carbon isotope composition of tree ring cellulose: an intercomparison of Quercus robur, Fagus sylvatica and Pinus silvestris. Tellus 50B:25-33.

Hunter RD, Panyushkina IP, Leavitt SW, Wiedenhoeft AC, Zawiskie J. 2006. A mid-Holocene submerged conifer forest in the southern Lake Huron Basin. Quaternary Research 66:67-77.

Kaiser KF. 1994. Two Creeks Interstade dated through dendrochronology and AMS. Quaternary Research 42(3):288-98

Kendall C, Coplen TB. 2002. Distribution of oxygen-18 and deuterium in river waters across the United States. Hydrological Processes 15:1363-93.

Kerwin M, Overpeck JT, Webb RS, DeVernal A, Rind DH, Healy RJ. 1999. The role of oceanic forcing in mid-Holocene Northern Hemisphere climatic change. Paleoceanography 14:200-10.

Leavitt SW. 2002. Prospects for reconstruction of seasonal environment from tree-ring $\delta^{13} \mathrm{C}$ : Baseline findings from the Great Lakes area, U.S.A. Chemical Geology 192(1-2):47-58.

Leavitt SW. Forthcoming. Regional expression of the 1988 U.S. Midwest drought in seasonal $\delta^{13} \mathrm{C}$ of tree rings. Journal of Geophysical Research - Atmo- spheres.

Leavitt SW, Long A. 1984. Sampling strategy for stable carbon isotope analysis of tree rings in pine. Nature 311:145-7.

Leavitt SW, Long A. 1986. Stable-carbon isotope variability in tree foliage and wood. Ecology 67:1002-10.

Leavitt SW, Long A. 1988. Intertree variability of $\delta^{13} \mathrm{C}$ in tree rings. In: Rundel PW, Ehleringer JR, Nagy KA, editors. Stable Isotopes in Ecological Research. Chapter 7. New York: Springer-Verlag. p 95-104.

Leavitt SW, Long A. 1989. Drought indicated in carbon13/carbon-12 ratios of southwestern tree rings. Water Resources Bulletin 25:341-7.

Leavitt SW, Kalin RM. 1992. A new tree-ring width, $\delta^{13} \mathrm{C}$ and ${ }^{14} \mathrm{C}$ investigation of the Two Creeks site. $R a$ diocarbon 34(3):792-7.

Leavitt SW, Newberry T. 1992. Systematics of stablecarbon isotopic differences between gymnosperm and angiosperm trees. Plant Physiology (Life Sci. Adv.) 11: 257-62.

Leavitt SW, Danzer SR. 1993. Method for batch processing small wood samples to holocellulose for stablecarbon isotope analysis. Analytical Chemistry 65:879

Leavitt SW, Wright WE, Long A. 2002. Spatial expression of ENSO, drought and summer monsoon in seasonal $\delta^{13} \mathrm{C}$ of ponderosa pine tree rings in southern Arizona and New Mexico. Journal of Geophysical Research 107(D18):4349. doi:10.1029/ 2001JD001312.

Lipp J, Trimborn P, Fritz P, Moser H, Becker B, Frenzel B. 1991. Stable isotopes in tree ring cellulose and climatic change. Tellus 43B:322-30.

Lowell TV, Larson GJ, Hughes JD, Denton GH. 1999. Age verification of the Lake Gribben forest bed and the Younger Dryas advance of the Laurentide ice sheet. Canadian Journal of Earth Science 36:383-93.

Mayr C, Frenzel B, Friedrich M, Spurk M, Stichler W, Trimborn P. 2003. Stable carbon- and hydrogen-isotope ratios of subfossil oaks in southern Germany: Methodology and application to a composite record for the Holocene. The Holocene 13:393-402.

Moran JM, Stieglitz RD, Quigley DP. 1988. Glacial geology, road construction in northeast Wisconsin reveals clues to Earth's natural history. Earth Science (winter):16-18.

Pranschke F, Schabica CW. 1993. The remains of an 8200 -year-old forest on the floor of southern Lake Michigan [final Report to the National Geographic Society]. Grant \#4748-92.

Pregitzer KS, Reed DD, Bornhorst TJ, Foster DR, Mroz GD, McLachlin JS, Laks PE, Stokke DD, Martin PE, Brown SE. 2000. A buried spruce forest provides evidence at the stand and landscape scale for the effects of environment on vegetation at the Pleistocene/Holocene boundary. Journal of Ecology 88:45-53. 
Ramesh R, Bhattacharya SK, Gopalan K. 1985. Dendrochronological implications of isotope coherence in trees from Kashmir Valley, India. Nature 317:802-4.

Reimer PJ, Baillie MGL, Bard E, Bayliss A, Beck JW, Bertrand CJH, Blackwell PG, Buck CE, Burr GS, Cutler KB, Damon PE, Edwards RL, Fairbanks RG, Friedrich M, Guilderson TP, Hogg AG, Hughen KA, Kromer B, McCormac FG, Manning SW, Ramsey CB, Reimer RW, Remmele S, Southon JR, Stuiver M, Talamo S, Taylor FW, van der Plicht J, Weyhenmeyer CE. 2004. IntCal04 terrestrial radiocarbon age calibration, 26-0 kyr BP. Radiocarbon 46(3):1029-58.

Roden JS, Lin G, Ehleringer JR. 1999. A mechanistic model for interpretation of hydrogen and oxygen isotope ratios in tree ring cellulose. Geochimica et Cosmochimica Acta 64:21-35.

Saurer M, Siegenthaler U. 1989. ${ }^{13} \mathrm{C} /{ }^{12} \mathrm{C}$ ratios in tree are sensitive to relative humidity. Dendrochronologia 7 : 9-13.

Saurer M, Borella S, Leuenberger M. 1997. $\delta^{18}$ O of tree rings of beech (Fagus silvatica) as a record of $\delta^{18} \mathrm{O}$ of the growing season precipitation. Tellus 49B:80-92.

Schneider AF, Hansel AK. 1990. Evidence for post-Two Creeks age of the type Calumet shoreline of glacial Lake Chicago. Geological Society of America Special Paper 251. p 1-8.

Shane LCK, Anderson KH. 1993. Intensity, gradients and reversals in late glacial environmental change in east-central North America. Quaternary Science Reviews 12:397-20.

Smith HJ, Fischer H, Mastroianni D, Deck B, Wahlen M. 1999. Dual modes of the carbon cycle since the last glacial maximum. Nature 400:248-50.

Sternberg LSL. 1989. Oxygen and hydrogen isotope measurements in plant cellulose analysis. In: Linskens HF, Jackson JF, editors. Plant Fibres. Modern Methods of Plant Analysis. Volume 10. New York: Springer-Verlag. p 89-99.

Stuiver M, Braziunas TF. 1987. Tree cellulose ${ }^{13} \mathrm{C} /{ }^{12} \mathrm{C}$ isotope ratios and climate change. Nature 328:58-60.

Stuiver M, Reimer PJ. 1993. Extended ${ }^{14} \mathrm{C}$ database and revised CALIB radiocarbon calibration program (Version 5.0). Radiocarbon 35(1):215-30.

Stuiver M, Reimer PJ, Braziunas TF. 1998. High-precision radiocarbon age calibration for terrestrial and marine samples. Radiocarbon 40(3):1127-51.

Thwaites FT. 1958. The Green Bay forest bed locality [unpublished manuscript]. 3 p.

Winkler MG, Swain AM, Kutzbach JE. 1986. MiddleHolocene dry period in the northern midwestern United States: lake levels and pollen stratigraphy. Quaternary Research 25:235-50.

Yakir D, DeNiro MJ. 1990. Oxygen and hydrogen isotope fractionation during cellulose metabolism in Lemna gibba L. Plant Physiology 93:325-32.

Yapp CJ, Epstein S. 1977. Climatic implications of D/H ratios of meteoric water over North America (950022,000 B.P.) as inferred from ancient wood cellulose C-H hydrogen. Earth and Planetary Science Letters 34:333-50.

Yapp CJ, Epstein S. 1982. Climatic significance of the hydrogen isotope ratios in tree cellulose. Nature 297: 636-9.

Yu Z. 2000. Ecosystem response to Lateglacial and early Holocene climate oscillations in the Great Lakes region of North America. Quaternary Science Reviews 19:1723-47. 